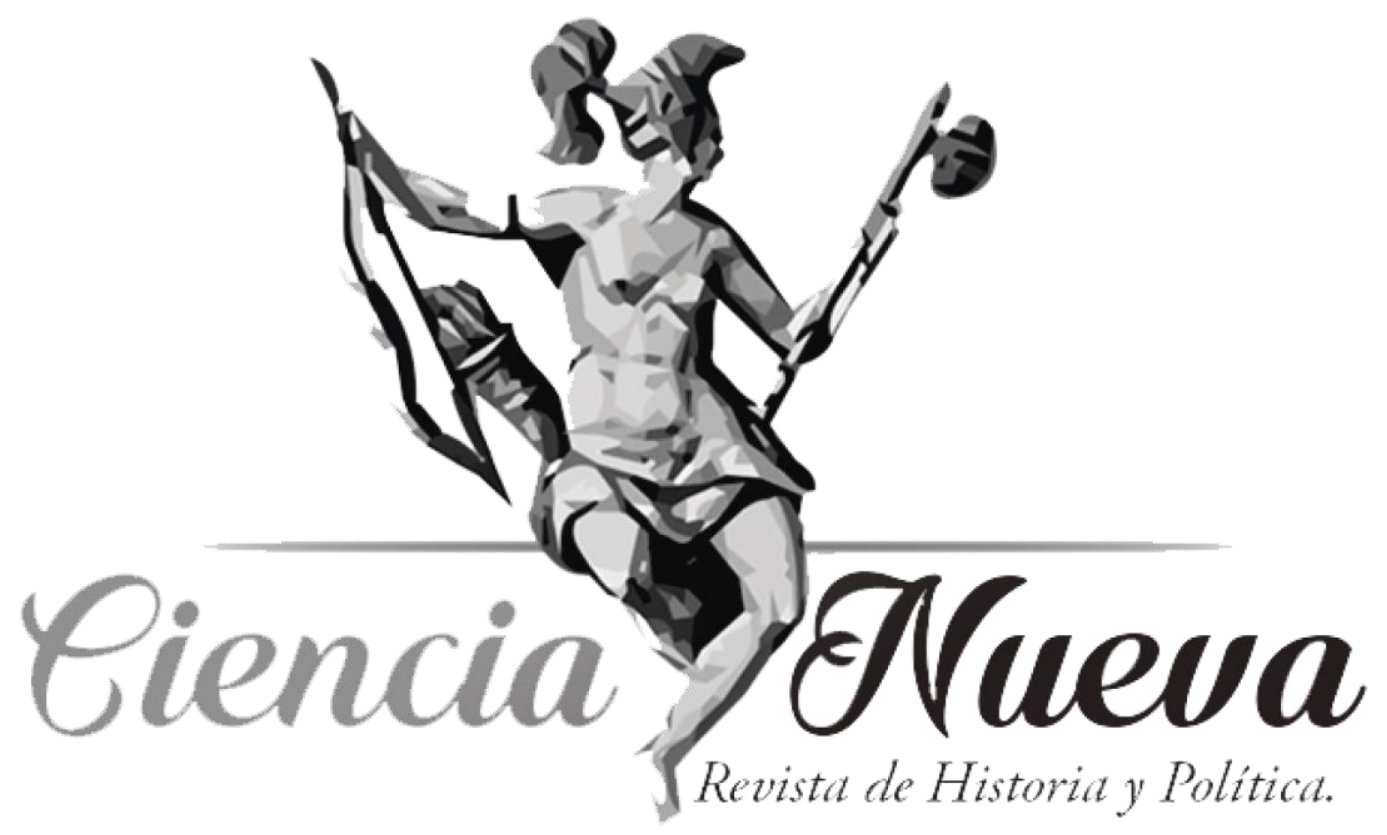

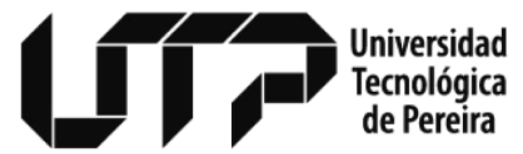

Maestría en Historia

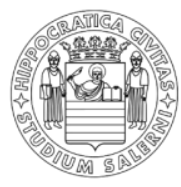

UNIVERSITÀ DEGLI STUDI DI SALERNO

Maestría en Ciencia Política

DOSSIER

GLOBAL PERSPECTIVES OF LATIN-AMERICAN HISTORY Daniel Emilio Rojas Castro (MCF), Guest Editor

THE TRANSNATIONAL FEMINIST MOVEMENT IN THE

AMERICAS IN THE 1930S

EL MOVIMIENTO FEMINISTA TRANSNACIONAL EN EL CONTINENTE AMERICANO EN 1930 DOI: https://doi.org/10.22517/25392662.22661

María Elvira Álvarez Giménez

pp. 113-133

Vol. 3 Núm. 1 | Enero-Junio de 2019

Pereira, Colombia 


\title{
THE TRANSNATIONAL FEMINIST MOVEMENT IN THE AMERICAS IN THE 1930S*
}

\section{EL MOVIMIENTO FEMINISTA TRANSNACIONAL EN EL CONTINENTE AMERICANO EN 1930}

\author{
María Elvira Álvarez Giménez,** \\ alvarez.mariaelvira@gmail.com \\ ORCID : http://orcid.org/0000-0003-0713-9809
}

$\begin{array}{cl}\text { Received: } & \text { February } 18^{\text {th }}, 2019 . \\ \text { Reviewed: } & \text { May } 4^{\text {th }}, 2019 . \\ \text { Accepted: } & \text { June } 19^{\text {th }}, 2019 . \\ \text { Published: } & \text { June } 30^{\text {th }}, 2019 .\end{array}$

\begin{abstract}
:
This paper aims to study how a transnational feminist movement emerged in the Americas and had a significant period of activity in the 1930s. It examines its goals and political strategies, as well as the impact of collective mobilization. Mobilizing collectively at the transnational and international level allowed feminists from the American continent to gain some victories as well as political legitimacy.

We will see how mobilizing collectively at the continental level served them as a strategy of struggle to acquire symbolic or material resources. At times, it increased the legitimacy of feminism that feminists were unable to obtain in their countries. The detour by the international was therefore extremely useful to them to put pressure on their governments. Besides, they did not conceive of their struggles in isolation. They believed that in order to obtain civil and political rights, but also the maintenance of peace on the continent, they had to build a collective struggle that transcended their borders.
\end{abstract}

Keywords: transnational feminist movement, Americas, 1930s, Inter-American Commission of Women.

\section{Resumen:}

Este trabajo pretende estudiar cómo surgió un movimiento feminista transnacional en el continente americano y tuvo un gran período de actividad en la década de 1930, cuáles fueron sus objetivos y estrategias políticas, y cómo la movilización colectiva a nivel transnacional e internacional permitió a las feministas del continente americano ganar algunas victorias, así como legitimidad política.

Veremos cómo la movilización colectiva a nivel del continente les sirvió como una estrategia de lucha para adquirir recursos simbólicos o materiales, así como una legitimidad que a veces no pudieron obtener en sus países. Luchar a través de foros internacionales fue, por lo tanto, extremadamente útil para ellas con el fin de presionar a sus gobiernos. Además, ellas no concebían sus luchas de manera aislada. Creían que, para obtener los derechos civiles y políticos, pero también el mantenimiento de la paz en el continente, tenían que construir una lucha colectiva que trascendiera sus fronteras.

Palabras clave: movimiento feminista transnacional, continente americano, década de 1930, Comisión Interamericana de Mujeres.

\footnotetext{
* This paper was written according to the Declaration on Publication Ethics of Ciencia Nueva, Revista de Historia y Política. This Declaration can be read on the journal's website: revistas.utp.edu.co/index.php/historia. ** Historian; PhD. in History from the University of Paris 1 Pantheon-Sorbonne. Her doctoral thesis, defended in December 2018, focuses on "Women in the Public Sphere in Bolivia from the Chaco War to the National Revolution (1935-1952)". Her Master's thesis, which has been published in French, deals with "The Feminist Movement and the Right to Vote in Bolivia (1920-1952)". For her doctoral thesis, she has been a beneficiary of the scholarship of her University and the scholarship of excellence from the organization "Graduate Women International". During the master's and doctorate, she has been an exchange student and guest researcher in the USA, at Columbia and Duke universities respectively. She has taught at the University of Paris 1 PantheonSorbonne, at the University of Havre and at the University of Cergy-Pontoise in France. She is currently an associate researcher at the Center for Research on Latin America and the Iberian World at the University of Paris 1 Pantheon-Sorbonne.
} 
Fifty thousand women have been watching Hermelinda U. de Brione's flight in her rented airplane.

For she is their symbol - a tiny, feminine, quiet girl, who has risen to the heights figuratively, in the hearts of their fellow-countrywomen. She is the symbol of the New Woman in Ecuador and all the Americas (...) Mrs. de Briones, who learned to fly at Curtiss Field on Long Island less than two years ago, visioned a tour of all the Americas to further the cause of peace. That, rather than flying, is her career. And that is why 50.000 women are watching her.

They are members of the Unión de Mujeres Americanas - something like the National Woman's Party here, except that the other organization is Pan-American. They believe in equality for women and peace $(. .$.

And now her interest [Hermelinda's] in peace is going to get her a new plane - all her own. It is to be bought by pennies and dimes contributed by women of North and South America who are interested in peace. As soon as she gets it, Mrs. de Briones said, she will start touring South America. She will stop wherever the "White Flag of Peace", adopted last year at the Montevidean conference, is known. And she will lecture peace and teach peace. For women, she believes, can not have "equality" until there is peace".

$\mathrm{O}$ n August 27, 1934, Hermelinda U. de Briones, an Ecuadorian aviator living in the United States, made a first flight from New York City to Washington D.C. inaugurating a tour that would take her on an intercontinental trip from North to South America with the objective of sponsoring peace and gender equality. The project of this tour was devised by the "Union of American Women", ("Unión de Mujeres Americanas", "UMA") a Pan-American feminist group founded the same year by the Mexican Margarita Robles de Mendoza, based in New York. The flight of this Ecuadorian was, as described by the journalists, a symbol for these feminists. It became the symbol of the way in which they conceived their struggle for peace and women's rights, a struggle that had to be carried out on the international level, and particularly at the continental level, in North and South America.

The Union of American Women, was one of the many feminist organizations that emerged in the 1930s with the aim of achieving civil and political rights for women in their countries and throughout the Americas in general. In fact, the feminists of the 1930s conceived of their struggle internationally, and above all intercontinentally; none of the feminist organizations of the American continent acted in isolation. The feminist leaders of the American continent (who pertained in their vast majority to the upper and middle classes of society), were all in contact with each other and therefore formed networks that sought to establish and maintain peace as well as achieve civil and political rights for women within their countries through international pressure. In fact, in order to achieve their goals at the national level they used international forums: they expected governments to sign international treaties granting them rights under the scrutiny of an "international public opinion" that would be measuring the progress of their countries under a "modernity" scale.

\footnotetext{
1 "Unión de Mujeres Americanas", Boxes 92.1-92.2, Series V. Inter-American Commission of Women, Doris Stevens' Collection, Arthur and Elizabeth Schlesinger Library on the History of Women in America, Radcliffe Institute for Advanced Studies, Harvard University, Boston, United States.
} 
To date, most of the studies conducted on the feminist movements of the first half of the $20^{\text {th }}$ century in the Americas, have been carried out within a national framework ${ }^{2}$. Few, but increasingly numerous, are the works on feminist movements in the American continent or in the world from a transnational perspective (but they are particularly focused on the feminist movements of the last three decades) ${ }^{3}$. However, when studying the feminist organizations of the American continent during the first half of the $20^{\text {th }}$ century, we quickly discover that these organizations in many cases were branches of feminist organizations based in other countries, or that the feminist leaders of these organizations maintained a dense and important correspondence with other feminists of the continent and that they frequently participated in international congresses. Therefore, studying the feminist organizations of the American continent under a national perspective is limiting because it does not allow us to understand correctly the visions with which they conceived their struggles or the strategies used by these organizations to achieve their objectives.

In the same way, there are few works that have been dedicated to study the existing links between Latin American and North American feminists, and how they conceived the feminist movement at a continental level. It is as if it was considered "natural" that the linguistic and/or cultural barriers between Latin and Anglo-Saxon women complicated communication between them, or that the relations established by the Saxons and Latinas were necessarily a "mirror" of the political hegemony that the United States exercised over Latin American countries. However, by closely studying the feminist organizations of the continent and the correspondence of their leaders we discover that the ties between North American and Latin American were much more important than it might seem at first, because

\footnotetext{
${ }^{2}$ To cite a few: Ana María Goetschel, Orígenes del feminismo en el Ecuador: Antología (Quito: CONAMU, 2006); June Edith Hahner, Emancipating the female sex: the struggle for women's rights in Brazil, $1850-1940$ (Durham: Duke University Press, 1990); Asunción Lavrin, Women, feminism, and social change in Argentina, Chile, and Uruguay, 1890-1940 (Lincoln Neb.: University of Nebraska Press, 1995); Lola G. Luna, El sujeto sufragista, feminismo y feminidad en Colombia 1930-1957 (Cali: La Manzana de la Discordia, 2004); Anna Macías, Against all odds: the feminist movement in Mexico to 1940 (Westport, CT: Greenwood Press, 1982 ); Jocelyn Olcott, Revolutionary women in postrevolutionary Mexico (Durham: Duke University Press, 2005); K. Lynn Stoner, From the house to the streets: the Cuban woman's movement for legal reform, 1898-1940 (Durham: Duke University Press, 1991).

${ }^{3}$ On the feminists movements of the first half of the 20th century:

Francesca Miller, Latin American women and the search for social justice (Hanover: University Press of New England, 1991); Francesca Miller, "Feminism and Foreign Policy in the Americas: Separate Conversations?" (WAWH Conference XXVI, California, June 3, 1995); Francesca Miller, "Latin American Feminism and the Transnational Arena", in Women, Culture, and Politics in Latin America, Emilie Bergmann et al. (University of California Press, 1992), doi10.1525/california/9780520065536.001.0001; Francesca Miller, "The International Relations of Women of the Americas, 1890-1928", The Americas: A Quarterly Review of InterAmerican Cultural History 43, n. ${ }^{\circ} 2$ (1986): 171-182; Leila J. Rupp, Worlds of Women: The Making of an International Women's Movement (Princeton, N.J: Princeton University Press, 1997); Mrinalini Sinha, Donna Guy \& Angela Woollacott, Feminisms and Internationalism (Wiley, 1999); Karen Offen, ed., Globalizing Feminisms, 1789- 1945, 1 edition (London; New York: Routledge, 2009); Megan Threlkeld, Pan-American Women: U.S. Internationalists and Revolutionary Mexico (University of Pennsylvania Press, 2014).

On the feminists movements of the last three decades:

Sonia E. Alvarez, "Translating the global: effects of transnational organizing on local feminist discourses and practices in Latin America", Meridians: feminism, race, transnationalism 1, n. ${ }^{\circ} 1$ (2000): 29-67; Myra Marx Ferree and Aili Mari Tripp, ed., Global feminism. Transnational women's activism, organizing, and Human Rights (NYU Press, 2006); Inderpal Grewal, Transnational America. Feminisms, diasporas, neoliberalisms (Durham \& London: Duke University Press, 2005).
} 
they conceived of their struggles at the intercontinental level under the framework of "PanAmericanism" and that the relationships established between them were more complex than simple unequal power relations between North American and Latin American women.

The questions that arise are: why did these feminist organizations seek to create links with organizations in other countries? What advantage did it give them to correspond with feminist leaders of other countries, to participate in international congresses, and to exchange magazines with other women of the continent? These are some of the questions we will try to answer in this paper. We will analyze how this transnational feminist movement was established, how the main feminist leaders of the continent met and managed to establish lasting relationships through a dense correspondence, the exchange of magazines, the organization and participation in international congresses and Pan-American meetings and the creation of Pan-American feminist organizations. We will also study the leading role that the Inter-American Commission of Women formed in the establishment and development of these networks in the 1930s and the role that it played in the relations and ties between Latin American and US feminists. Finally, we will study the pacifist objectives of the transnational feminist movement at a continental and global level in a context in which Bolivia and Paraguay faced each other in a bloody conflict, the Chaco War (1932-1935) (which was central in the feminist discourse for peace), and in which the fears of a new world confrontation were strongly felt in the 1930s.

\section{Origins and formation of the transnational feminist movement in the Americas}

According to Francesca Miller ${ }^{4}$, the origins of the constitution of Pan-American feminist networks go back to the organization of scientific congresses in South America that took place from 1898 to 1916 . These congresses served as the forums that allowed the meeting and the conformation of friendships and solidarities among the women who participated and thus allowed the establishment of ties between the first feminists from the American continent. In 1898 the Argentine Scientific Society inaugurated a series of scientific congresses. The women who participated were usually the first women that obtained university degrees in their countries. As it happened in the subsequent congresses that took place in Montevideo in 1901, Rio de Janeiro in 1905-1906, Santiago in 1908-1909 the majority of the women that participated came from the countries of the southern cone: Argentina, Chile, Uruguay and Brazil. On May 10, 1910, the First International Feminine Congress was organized in Buenos Aires, where almost 2000 women from Peru, Chile, Uruguay, Paraguay and Argentina attended ${ }^{5}$.

However, when women were not invited to one of the scientific Congresses that took place in Washington in 1915 and 1916, they decided to organize the "First Pan-American Auxiliary Conference for Women". The most important result of this conference was the decision to create a Pan-American women's union that came to be called: International Committee of Pan-American Women ${ }^{6}$.

In the following years, this organization contributed to the creation of stronger and closer ties among the women of the continent through the publication of reports and articles of the organization that were distributed by all the countries through the national committees.

\footnotetext{
${ }^{4}$ Francesca Miller, "The International Relations of Women of the Americas, 1890-1928".

${ }^{5}$ Francesca Miller, "The International Relations of Women of the Americas, 1890-1928".

${ }^{6}$ Francesca Miller, "The International Relations of Women of the Americas, 1890-1928”.
} 
This organization laid the foundations for what would be a real and permanent organization of mobilization and joint work of the women of the continent. Continuing with these activities, in 1922, the National League of Women Voters, together with the International Committee of Pan-American Women organized a Pan-American Conference of Women in the city of Baltimore, United States. With more than 2000 participants, the Baltimore Congress constituted the largest women's meeting ever ${ }^{7}$.

Thus, the scientific congresses of the beginning of the century allowed the meeting between the intellectual and feminist women of the continent who organized themselves into Pan-American groups that aimed to fight for their rights under a "Pan-Americanist" perspective. These first organizations laid the foundations for the creation of dense, solid networks and the mutual cooperation and mobilization of the women of the continent ${ }^{8}$.

These efforts were fruitful and had a significant impact on the following Pan-American conferences: for the Sixth Pan-American Conference that took place in Havana in 1928, women from all over the continent had gathered there for the Inter-American meeting. The main feminist organizations of the continent were present. At the end of the conference, these women managed to obtain a hearing in one of the plenary sessions, in which they presented a Treaty of Equal Rights to be considered by the governments of the continent, and they pressed for the creation of an official body in charge of investigating the legal status of women in the 21 member countries of the Pan-American Union ${ }^{9}$. Thus, was born in 1928 the Inter-American Commission of Women (IACW), an official and autonomous agency of the Pan-American Union, the first intergovernmental organization in the world founded expressly to deal with the investigation of the condition of women in the continent and therefore to fight for obtaining equal rights ${ }^{10}$.

\section{The Inter-American Commission of Women and the relations between Latin American and US feminists}

The ties between American feminists did not revolve or were structured only around the Inter-American Commission of Women (IACW), but the creation of this organization came to crown the efforts made by them since they decided to create the International Committee of Pan-American Women in 1916. This time they had an institution that was an agency of the Pan-American Union, that is, an official agency through which they could achieve their objectives of obtaining civil and political rights.

The IACW was in charge of investigating the condition of women throughout the continent and presenting a report of that research at the next Pan-American conference in which treaties would be signed to abolish inequalities between men and women in all the countries of the continent. The IACW was therefore a triumph in the quest for feminists for political legitimacy and was the main agency through which US and Latin American women related. The president of the IACW, Doris Stevens, a famous US suffragist member of the National Women's Party of the United States, was to work together with another 21 women representatives from each of the member countries of the Pan-American Union.

\footnotetext{
${ }^{7}$ Francesca Miller, "The International Relations of Women of the Americas, 1890-1928”.

${ }^{8}$ Francesca Miller, "The International Relations of Women of the Americas, 1890-1928”.

${ }^{9}$ Francesca Miller, "The International Relations of Women of the Americas, 1890-1928".

${ }^{10}$ Francesca Miller, “The International Relations of Women of the Americas, 1890-1928".
} 
Since its inception, the IACW did not benefit from many facilities. They were given a tiny unheated office in the Pan American Union building in Washington. They did not receive any financial help, and they could only start their work thanks to an aid received from the Carnegie Endowment for International Peace of 5 thousand dollars. At the beginning, Doris Stevens and her secretary Fanny Bunand-Sévastos performed all the administrative work together with the few commissioners present in Washington. Their task was not easy: in addition to the lack of heating and staff, they often had to deal with the fact that their desks had been "borrowed" or that all the chairs in their office were missing ${ }^{11}$.

The positions in the IACW were honorary and therefore none of the commissioners benefited from any type of remuneration from either the Pan-American Union or their own governments (although the latter had the capacity to decide whether or not they wanted to remunerate their representatives). This prevented many feminist leaders of the continent from being part of the IACW because they did not have the economic means to work in an honorary manner or to travel to Washington. It is for this reason that many of the initial members of the organization were not necessarily feminist militants in their countries, but wives of the diplomatic representatives of their governments in Washington. In fact, the procedure by which the representatives were appointed was slow and depended on the good will of each of the governments. Leo S. Rowe, president of the Pan-American Union, sent a letter to the Minister of Foreign Affairs of each of the member countries, urging them to appoint a representative to the IACW. This simple procedure in appearance, did not always give results. In many cases governments did not respond, so Leo $\mathrm{S}$. Rowe and Doris Stevens had to request the intervention of the plenipotentiary ministers of each country in Washington. These epistolary exchanges could last for many months and even years until a representative was appointed. In order to begin its work, the IACW needed a maximum number of commissioners, above all because its first meeting was going to take place quite early, in February 1930 at the University of Havana. The IACW had until then 7 founding members and had to confirm there the 14 missing representatives. Some were named at the last minute as was the case of Margarita Robles de Mendoza from Mexico, who was appointed by her government days before the first meeting in Havana. However, some governments never responded to the requests of the IACW to appoint a representative: this is the case of Bolivia, which appointed a delegate in 1938, that is, 10 years after the founding of the organization! $!^{12}$.

Many of the governments, as we already mentioned, were content to appoint the wives of their diplomatic representatives in Washington given the fact that these women were already in Washington and had the means to work in an honorary manner. However, not all IACW commissioners were wives of diplomats; several of them were true feminist leaders. They were named by their governments for their commitment for women's rights in their countries or because Doris Stevens had suggested their names. In this way, the IACW had a mixture of diplomats' wives, experienced feminist militants as well as intellectual women, writers, poetesses, recognized in their own countries. This was the case of the first delegates of the IACW: Clara González of Panama (first woman to obtain the title of lawyer in her country and founder of the National Feminist Party), of Ernestina López de Nelson of

\footnotetext{
${ }^{11}$ Francesca Miller, "Latin American Feminism and the Transnational Arena".

12 “Appointment of commissioners, 1928-1938", Boxes 60.10-60.12, Series V. Inter-American Commission of Women, Doris Stevens' Collection. The Arthur and Elizabeth Schlesinger Library on the History of Women in America.
} 
Argentina (professor and writer, professor in the University of La Plata, President of the Mothers Club of Buenos Aires), Lucila Luciani de Pérez Díaz de Venezuela (historian and editor of the feminist magazine "Iris"), and many others ${ }^{13}$. Without having the same background, all of these women had something in common: they were upper middle class and middle class women who belonged to the social and intellectual elites of their countries.

In effect, the social environment from which most of these women came allowed them to have certain privileges, both economic and cultural, since most of them had received a privileged education. Many of these women were fluent in English or French, so communication between them and the Americans did not seem to be a real difficulty. Doris Stevens correspondence with Latin American women is impressive for its density. Most of the exchanged letters are in English, in Spanish, but also in French. Doris Stevens had the services of a translator who translated the letters she sent to Spanish, and those she received into English, even though she apparently had basic knowledge of Spanish, and was fluent in French, as she corresponded with many of the Latin American in French, the official language of diplomacy.

Although many of these women had sufficient financial means to work in an honorary manner and make frequent trips to Washington, many others had economic difficulties. The fact that they were still able to work for the IACW and participate in the Pan-American conferences in spite of these difficulties, was mainly due to the mutual help they provided each other based on bonds of solidarity, trust and friendship. These women exchanged not only information, fighting strategies, but also financial help.

This is the case, for example, of Margarita Robles de Mendoza, commissioned by Mexico in the IACW, and founder in 1934 of the Union of American Women. Margarita is one of the women with whom Doris Stevens maintained a dense and important correspondence. At a time when Margarita expressed that she suffered from a deplorable economic situation in Mexico and personal problems, Doris Stevens helped her financing a trip to Washington, her stay at the house of the National Women's Party, a salary to live in exchange for administrative services in the IACW, and the trip back to Mexico a few months later for Margarita to begin an intensive campaign for female suffrage in Mexico. This economic help was provided by Doris Stevens through the IACW after Margarita had written numerous letters to her government, asking him to recognize her work as commissioned by Mexico through a salary, a demand that was always denied to her by the Mexican government that did not even want to recognize her as a permanent delegate of Mexico in the IACW at that moment! ${ }^{14}$.

Thus, Doris Stevens was responsible for financing the travel of many of the commissioners, as was also the case of Marta Vergara, commissioned by Chile in the IACW, to participate in Assemblies of the League of Nations in The Hague where treaties were

\footnotetext{
${ }^{13}$ Muna Lee, "The Inter-American Commission of Women. A New International Venture", in A Pan-American Life: Selected Poetry and Prose of Muna Lee (Univ. of Wisconsin Press, 2004).

14 “México, Margarita Robles de Mendoza, 1930-1938”, Boxes 77.6-77.9, Series V. Inter-American Commission of Women, Doris Stevens' Collection. The Arthur and Elizabeth Schlesinger Library on the History of Women in America.
} 
discussed on the nationality of women ${ }^{15}$. The few resources that the IACW had to help its commissioners came mainly from donations from women in the United States ${ }^{16}$.

But the Latin Americans were not the only beneficiaries of this aid; US feminists also benefited from the hospitality of Latin American feminists when they were attending the different conferences that took place in the Latin American countries, such as the PanAmerican conferences of Montevideo in 1933 or Lima in 1938. The Americans stayed in the houses of many of the Latin American feminists, which allowed them to make considerable savings ${ }^{17}$.

On the other hand, these feminists also exchanged immaterial resources such as information, experiences and strategies of struggle, as well as help and symbolic support. For example, when discusions began in Ecuador at the end of 1935 to annul women's suffrage that had been granted to Ecuadorians through the 1929 Constitution, Doris Stevens and all the Latin American feminists of the continent began an intense campaign to demand from the Ecuadorian government the maintenance of that right, by sending letters to the president and to many of the representatives of the Ecuadorian government. In the same way, when Doris Stevens suffered attacks by Eleanor Roosevelt, during the Roosevelt administration in 1938 to be removed from the presidency of the IACW ${ }^{18}$, all Latin American feminists began a campaign through the press and the sending of letters to the United States government to protest against the attacks suffered by Doris Stevens.

Having obtained the right to vote in 1920 after long years of struggle in which US suffragists had to devise various strategies to obtain suffrage, it seemed natural that they should become models for Latin American suffragists. What influence did US feminists have on Latin American feminists? And, in what sense did this influence create relations of power among them or feelings of hostility and distrust on the part of Latin Americans towards the North Americans?

In many of the feminist magazines published in the Latin American countries in the 1930s (that we will examine later), the US feminists clearly appear as a model to be followed and the United States as the most advanced country for granting the right to vote to women relatively early. Doris Stevens, had the aura of a heroine and for many Latin Americans she represented an icon of struggle for women's suffrage. In effect, Stevens was one of the women, members of the National Women's Party who performed the famous and numerous marches and demonstrations in front of the White House demanding women's suffrage. In 1917 she was arrested along with her companions, and in 1920 she recounted this experience in her book Jailed for Freedom, which was translated into Spanish in the 1930s in Argentina and Chile by the feminists of those $\operatorname{countries}^{19}$. Doris Stevens was therefore a symbolic woman and therefore benefited from great prestige and admiration from Latin American

\footnotetext{
15 "Chile, Marta Vergara, 1930-1938”, Box 64.7, Series V. Inter-American Commission of Women, Doris Stevens' Collection. The Arthur and Elizabeth Schlesinger Library on the History of Women in America.

16 “Chile, Marta Vergara, 1930-1938”, Box 64.7, Series V.

17 “Chile, Marta Vergara, 1930-1938”, Box 64.7, Series V.

18 The IACW and Doris Stevens had never had the support of the diplomatic corps of the United States, and during the Roosevelt administration, Eleanor Roosevelt undertook all possible means to remove Doris Stevens from the presidency of the IACW and to make this organism put aside its feminist goals. Finally Eleanor Roosevelt achieved her objective: Doris Stevens was dismissed in 1939.

19 "Chile, Marta Vergara, 1930-1938", Box 64.7, Series V. Inter-American Commission of Women, Doris Stevens' Collection. The Arthur and Elizabeth Schlesinger Library on the History of Women in America.
} 
feminists and even more from her work as President of the IACW and her strong implication in the suffrage struggles of all the countries of the hemisphere.

However, for ideological reasons as well as political or personal hostility, US feminists raised ambivalent feelings among Latin Americans. Numerous are the articles in the feminist magazines of the 1920s and 1930s that were published in Latin American countries, in which feminism is discussed and two types of feminism are defined. The first type is the one hoisted by Anglo-Saxon women, US and English, a "grotesque", "hysterical", "masculine" and "masculinizing" feminism that Latin American feminists denounced because they repudiated the spectacular actions of the English and US "suffragettes". According to these articles, Latin American feminists would never "debase themselves" by throwing stones at buildings, being chained or going on hunger strikes to achieve their rights. For them, feminism and the struggle for women's rights should be carried out through rational and moderate debate, and in no case should feminists lose their "femininity" or want to displace men in their activities. If women demanded rights it was to better fulfil their role as mothers and educators of the men who would forge the future of the "fatherland". Latin American women did not pretend to be equal to men, but they wanted to stop being their "slaves" and become their "companions" through the "complementation of the sexes". This was what Latin American feminists called the "well-understood feminism"20, which opposed the "misunderstood," "aggressive," and "masculinizing" feminism of the Anglo-Saxons. In that sense, Latin American feminists distanced themselves ideologically from the English and North American women and paradoxically saw them as examples not to follow, since according to them the Anglo-Saxons had lost their "femininity", they had stopped being "women" causing a "great harm" to society. This idea is developed, for example, by the young Bolivian feminist María Teresa Urquidi, a student in 1933 at the University of San Mateo in San Francisco, California, in the feminist magazine published in Buenos Aires from 1933 to 1935, "Mujeres de América":

Debido a nuestra larga permanencia en el paraíso de las mujeres, Estados Unidos, nos parece curioso que aun haya países donde el voto femenino no existe. ¡Tan natural es por estas tierras ver a las mujeres dejar sus cocinas, sus quehaceres domésticos, sus talleres o sus oficinas, para tomar el automóvil y dirigirse a las urnas el día de elecciones! Hemos dicho curioso, pero no triste, porque todavía no alcanzamos a ver las ventajas, que las mujeres que van a las urnas han ganado sobre las que no van.

Cuando la mayor parte de los países sajones dio el voto a la mujer, se esperó que su acción sería eficaz en el campo de la legislación social. Es doloroso decir que esa eficacia aun no se ha dejado sentir, a pesar de que ya había tiempo para ello. Hay algo peor todavía; la mujer en los Estados Unidos muestra una tendencia formidable a perder su feminidad. No podemos asegurar que la pioneer norteamericana hubiera poseído tal cualidad en grado sumo, pero podemos afirmar que una considerable mayoría de sus descendientes (mujeres) carece de ella. ¿Debe esto a su participación en política? Opiniones autorizadas y serenas dicen que sí, y añaden: "antes teníamos mejores esposas y madres en este país". Aunque no aceptamos esta

\footnotetext{
${ }^{20}$ Mercedes Prieto \& Ana María Goetschel, "El sufragio femenino en el Ecuador, 1884-1940”, in ¿Qué género tiene el derecho? Ciudadanía, historia y globalización, ed. by Stefanie Kron y Karoline Noack (Berlín: Edition Tranvía, Verlag Walter Frey, 2008).
} 
opinión en su totalidad, sospechamos que hay relación indirecta de causa y efecto entre los dos hechos.

Individualmente considerada, la mujer es inmensamente más feliz bajo el actual régimen libre de lo que era cuando las leyes y la sociedad limitaban rigurosamente su acción. En su calidad de ser humano ella tiene derecho absoluto a esa felicidad, pero aquí viene el eterno interrogante: ¿Cuál merece el primer puesto, el individuo o la sociedad? Y la sociedad pierde cuando sus mujeres dejan de ser mujeres. Cuando esto ocurre, esas grandes cualidades del sexo, una vez llamado bello, su intuición, su generosidad, su comprensión y su facilidad de adaptación, desaparecen, y con ello sufre una pérdida grave la humanidad ${ }^{21}$.

To this ideological distancing of the Latin Americans towards the Anglo-Saxons, there was also an estrangement for political or even personal reasons. In fact, even though Doris Stevens corresponded with the feminist leaders of all the Latin American countries, this did not mean that she had a good relationships with all of them. A good example of this is the case of the Uruguayan Paulina Luisi who felt a deep distrust for Doris Stevens and the North Americans in general. Paulina Luisi was the most important feminist leader at the beginning of the century in Uruguay. She was the first woman doctor of her country and the founder and leader of the National Council of Women of Uruguay, the largest and most important feminist organization in the country and the one most involved in the struggle for women's suffrage. Paulina Luisi was well known in Latin America, Europe and the United States, thanks to her frequent trips. She was also the only Latin American woman who was among the leaders of the International Women's Suffrage Alliance (IWSA), later converted into International Alliance of Women (IAW), being the vice-president of that organization from 1923 to $1926^{22}$.

Being one of the most prominent feminist leaders among Latin Americans, it was to be expected that she and Doris Stevens would maintain strong ties, but this was not the case. In March of 1932, Paulina Luisi, who was in Europe, was invited by Alice Paul (also a famous U.S. suffragist who fought alongside Doris Stevens in the campaigns for women's suffrage) to be part of the Committee for the Nationality of the IACW in charge to pressure the League of Nations in Geneva to vote on resolutions to force all the states in the world to legislate so that women would not lose their nationality when married to a foreigner. Paulina Luisi accepted the invitation but with reluctance, because she was apparently angry that she had not been named representative of Uruguay in the $\mathrm{IACW}^{23}$, and it had bothered her that she had also received the welcome letter from Doris Stevens in English ${ }^{24}$. Marta Vergara, a Chilean feminist who was also part of the Nationality Committee in Geneva, wrote to Doris Stevens commenting on Paulina Luisi's attitude in this regard, to which the latter responded:

\footnotetext{
${ }^{21}$ Mujeres de América, Year 1, Buenos Aires, July-August 1933, No4, National Library of the Argentine Republic, Buenos Aires, Argentina.

${ }^{22}$ Christine Ehrick, "Madrinas and Missionaries: Uruguay and the Pan-American Women's Movement", in Sinha Mrinalini, Guy Donna \& Woollacott Angela, Feminisms and Internationalism, (Wiley, 1999).

${ }^{23}$ Letter from Doris Stevens to Alice Paul, 22 de abril de 1932, “Appointment of Commissioners, 1928-1938”, Boxes 60.10-60.12, Series V. Inter-American Commission of Women, Doris Stevens' Collection. The Arthur and Elizabeth Schlesinger Library on the History of Women in America.

${ }^{24}$ This is the only case in which the language seems to have created communication problems between Latin American and American women.
} 
I was astonished to get your report on Paulina Luisi's attitude after my cordial letter welcoming her to membership on the Nationality Committee of the Commission. I wondered why she had not answered. I thought she told me in Berlin that she understood English. At any rate it would not be very difficult in Geneva to have it translated.

She quite terrified me in Berlin. However, as you say, she is so excellent a feminist that one would wish to work with her if possible. Meanwhile I have taken no further steps toward having a Uruguayan appointed to the Commission. I continue to reflect. Thank you so much for your letter.

Affectionately,

Chairman ${ }^{25}$.

It is not surprising then that the correspondence exchanged between Doris Stevens and Paulina Luisi is very limited. It is evident that Luisi never participated in any of the activities of the IACW. According to Christine Ehrick ${ }^{26}$, Luisi was very suspicious of North American women and feminists since the 1920s when in a congress of the International Women's Suffrage Association that took place in Geneva, the feminists of the countries of the North who had already obtained the women's suffrage, dissolved the association because they considered that their objectives had already been achieved. Luisi was enraged by the lack of internationalist vision of these feminists, which is why she wrote that the feminists of the north: "...demonstrated with this proposition the low opinion that the International feminist world has of the Latin countries"27.

In the same way, Elena Arizmendi, a Mexican feminist living in New York, who was vice-president and later president of the International League of Iberian and Hispanic Women $^{28}$, wrote several letters to Paulina Luisi in which she expressed her distrust of the IACW, of Doris Stevens and of US feminists in general, to which Luisi responded in a letter of November 26, 1930: “...with respect to Miss Stevens, I have known for a long time what to expect from her and her group. It is not news to me"29.

According to Christine Ehrick, the International League of Iberian and Hispanic American Women, was an organization created by Latin American women in response to the growing dominance in international feminism by feminists from certain countries of Europe and North America. It was then a matter of creating an own Hispanic-American organization that would aim to unite women of Hispanic culture in Latin America and Spain. Paulina Luisi was one of the leaders of this organization, of which she was vice-president for many years. Apparently, this group was founded in 1922, at the same time as its magazine "Feminismo Internacional". Regrettably little is known about this organization, but during the 1920s the

\footnotetext{
${ }^{25}$ Letter from Doris Stevens to Marta Vergara del 25 de mayo de 1932, "Chile, Marta Vergara, 1930-1938", Box 64.7, "Series V. Inter-American Commission of Women", Doris Stevens' Collection. The Arthur and Elizabeth Schlesinger Library on the History of Women in America.

${ }^{26}$ Christine Ehrick, "Madrinas and Missionaries: Uruguay and the Pan-American Women's Movement", in Feminisms and Internationalism, Mrinalini Sinha, Donna Guy \&Angela Woollacott (Wiley, 1999).

${ }^{27}$ Christine Ehrick, "Madrinas and Missionaries: Uruguay and the Pan-American Women's Movement".

${ }^{28}$ Liga Internacional de Mujeres Ibéricas e Hispanoamericanas.

${ }^{29}$ Quoted in Christine Ehrick, "Madrinas and Missionaries: Uruguay and the Pan-American Women's Movement".
} 
presidency was in charge of Carmen Burgos a Spanish writer from Madrid, and in the 1930s by the aforementioned Elena Arizmendi who lived in New York. This organization would have served as a kind of alternative to the IACW, which according to Christine Ehrick was dominated by the Americans: "The circumstances of its formation and the history of its early years notwithstanding, in later years the Iberian and Hispanic-American Women's League existed in part as an alternative to the Inter-American Commission of Women (IACW), an organization founded in 1930 and which remained firmly in control of North American women during the years in question. Beyond its opposition to the US, and by extension to the IACW, the politics of the Iberian and Hispanic League are somewhat difficult to classify. The rhetoric is highly nationalistic, and expresses a strong Pan-Hispanic ideology, but vacillates between a right-wing nationalism praising social elites and defending the status quo against "Yankee imperialism", and a more left-leaning nationalism which decries foreign intervention and calls for more substantive changes in social and property relations" 30 . The antipathy and hostility shown by many of the Latin Americans towards the North Americans was evidently linked to the growing anti-imperialist sentiment in Latin America against the United States because of its increasingly aggressive interventionist policies ${ }^{31}$.

In this way, it would be easy to conclude that the North Americans and especially the US feminists exerted a domination over the Latin Americans through the IACW supported by a feeling of superiority. However, in examining the relationships of these groups more closely we realize that, while some of the feminists perceived a desire for domination or feelings of superiority on the part of their U.S. counterparts, as was the case of the Uruguayan Paulina Luisi or the Brazilian Bertha Lutz, the IACW was not totally dominated by US feminists because the Latin Americans played a leading role in the organization and even in the survival of it.

Despite the fact that the United States represented the dominant country in PanAmerican international relations, Latin American women were a vast majority in the IACW. The US women were represented mainly by Doris Stevens (who was the president), and by the delegate from the United States to the $\mathrm{IACW}^{32}$. Stevens had therefore to work with 20 Latin Americans, who had a very important presence and prominence in the institution. The Latin American feminist leaders were the true allies of Stevens to continue the feminist policies of the IACW. In effect, Doris Stevens and the IACW never benefited from the support of the United States diplomatic corps, and during the Roosevelt administration, Doris Stevens suffered the attacks of the president's wife to be dismissed. In other words, Stevens not only did not benefit from the support of his government, but also the US government was hostile to her and the IACW for his feminist policies. Therefore, the delegates of the United States appointed by the government were not feminists and were in charge of turning the IACW into a social aid agency, thus removing all its feminist character and purposes. In this way, on many occasions Doris Stevens was forced to oppose the initiatives of the delegates of the United States, relying on the Latin American commissioners, who represented a majority as previously stated.

As for the activities of the IACW, the first objective was to investigate the legal status of women living in the 21 republics of the American continent and submit a report to the seventh Pan-American conference. This conference was held from December 3 to 26, 1933

\footnotetext{
${ }^{30}$ Christine Ehrick, "Madrinas and Missionaries: Uruguay and the Pan-American Women's Movement".

${ }^{31}$ Christine Ehrick, "Madrinas and Missionaries: Uruguay and the Pan-American Women's Movement".

${ }^{32}$ At that time, Canada was not part of the Pan American Union.
} 
in the city of Montevideo. The IACW was able to present a report with the results of its investigations. It is worth noting that it was the first time in the world that a study was made, exclusively by women, on the laws that affected them in terms of civil and political rights. As a result of this study, the IACW recommended a Treaty on Equality of Rights and a Convention on Nationality. The conference considered that the issue of equal rights was not an issue to be legislated at the international level, so the Treaty on Equality of Rights was only signed by four countries: Uruguay, Paraguay, Ecuador and Cuba, and it was not approved $^{33}$. A recommendation was approved (which the countries were not obliged to comply with) that made explicit the idea that women's rights were not an issue to be legislated at the international level as this would undermine the sovereignty of States. However, the Convention whereby a woman married to a foreigner should not lose their nationality was approved by 19 countries and this, (like the fact that the continuation of the IACW in its functions was voted), was a triumph for women from the American continent ${ }^{34}$. The IACW continued its international struggle in other international conferences. In 1938, in the eighth Pan-American conference that took place in Lima, in addition to becoming a permanent organism, the IACW achieved the approval of the "Declaration of Lima in favor of Women's Rights" which stipulated the need for countries of the continent to legislate in favor of equality of civil and political rights ${ }^{35}$.

Although the Commission was a body that played a leading role in the creation and maintenance of ties among feminists, it was not the only structure for women on the continent. Other organizations emerged in the 1930s, which, in addition to having as its objective the struggle for women's civil and political rights, gave great importance to the struggle for the maintenance of peace in the continent.

\section{A continental feminist and pacifist movement}

The Chaco War that opposed Bolivia and Paraguay from 1932 to 1935 was the only international war that took place in the American continent in the first half of the $20^{\text {th }}$ century. It marked many consciences and worried the feminists, particularly the South American women, for whom the conflict occurred near their borders. This is why Ecuadorians, Colombians, Chileans, Argentines, etc., mobilized at the continental level not only to obtain the civil and political rights of women but also to obtain guarantees of continental and world peace in a context in which the threat of a second world war was also real.

In the 1930s, the IACW was not the only organization with a Pan-American vocation. Many groups in the continent were not only corresponding and strengthening ties with each other, but organizations of an essentially Pan-American nature were also being formed to fight for women's rights and for peace. This is the case of the Women's Legion of Popular Education of Ecuador (Legión Femenina de Educación Popular América, LFEPA), founded in December 1932 in Guayaquil by the Ecuadorian writer Rosa Borja de Icaza. This feminist writer founded the organization in the main cities of Ecuador, and soon branches of the Legion were created in Colombia, Chile, Bolivia, Panama and Venezuela. The basic objectives of the organization were "the education of the masses", "the intellectual, cultural

\footnotetext{
${ }^{33}$ Asociación Civil "La mujer y el v centenario de América y Venezuela", Historia de la CIM, 1928-1992. Comisión Interamericana de la Organización de los Estados Americanos (OEA), Edición Homenaje del Congreso de la República de Caracas, Venezuela (1996), 30-31.

${ }^{34}$ Asociación Civil "La mujer y el v centenario de América y Venezuela".

35 Asociación Civil "La mujer y el v centenario de América y Venezuela", 33-34.
} 
and moral elevation of women", as well as the extension of the organization to other countries of the continent and the creation of links with feminist organizations of Latin America and the world. The organization had schools for workers, dining rooms, agricultural farms and popular libraries. It also frequently organized campaigns against alcoholism, medical conferences, parties and charity events.

The spokesman for the organization was the magazine entitled "Nuevos Horizontes" that circulated in most of the countries of the continent and that was published from 1933 to 1937, first every month and then more sporadically. Most of the information of the LFEPA is known through this magazine. In it were published (besides poems and stories), articles on feminism, as well as collaborations of other feminists of the continent. In almost every issue there was an article about women's struggle for peace and the need for feminists to organize to stop "the massacre of war". In fact, Rosa Borja de Icaza had the project to hold a Latin American Women's Congress, with the aim of discussing the issues that were of interest to the women of the continent: their rights and peace. As we will see later, she was not the only one with this project.

The LFEPA from its beginnings maintained very close ties with Delia Ducoing de Arrate (whose pseudonym was Isabel Morel), a feminist writer and educator, president of the Feminine Union of Chile ("Unión Femenina de Chile", "UFCH"). This organization edited the magazine "Nosotras" that was published for the first time in August 1931 in the city of Valparaíso and continued across a long life span reaching 65 editions, the last being published in May-June 1935. In its beginnings it was edited by the Feminine Union of Chile, feminist organization that was founded in Valparaiso in 1927 by Aurora Argomedo who was its first president $^{36}$. In 1928, Delia Ducoing de Arrate was named president of the organization until December 1933 when the magazine "Nosotras" separated from the Women's Union of Chile and moved its offices to Santiago de Chile, becoming the organ of the "Legion Femenina América" directed by the same Delia Ducoing who was the director of the magazine throughout its duration from 1931 to 1935.

Initially, the magazine focused mainly on national news and the monitoring of the campaign for women's suffrage in Chile. International feminist news appeared infrequently. The magazine "Nosotras" took on a much more internationalist character from 1932 with the increasingly frequent appearance of news about the international and Latin American feminist movement, but notably from 1933, when Delia Ducoing de Arrate came into contact with Rosa Borja of Icaza. From that moment the magazine "Nosotras" began to internationalize. Articles on peace, war and the role of women in maintaining the peace of the continent became more frequent. The armed conflict between Colombia and Peru from 1932 to 1933 and most importantly the Chaco War preoccupied the feminists of "Nosotras" and "Nuevos Horizontes".

Both in "Nuevos Horizontes" and in "Nosotras" the articles on the role of the American women in the fight against war and on the horrors of the Chaco War were innumerable. In fact, at the end of 1934, Olga C. de Veloso, Chilean legionary, sent a "Message to the mothers of Bolivia and Paraguay and to all the women of America" that the magazine "Nuevos Horizontes" published in November-December 1934, in which she called on all American women to unite to fight the war. Various organizations answered the call such as the Women's Legion of Popular Education of Colombia, the Mother and Home Society of Lima, the Union of American Women, and other non-feminist organizations whose objectives were purely

\footnotetext{
${ }^{36}$ Nosotras, Year 1, Valparaíso, November $7^{\text {th }} 1931, n^{\circ} 8$, National Library of Chile, Santiago, Chile.
} 
pacifists such as the Women's Confederation of American Peace of Buenos Aires or the International League for Peace and Freedom of the United States; all organizations with which the Women's Legion of Popular Education of Ecuador maintained close ties ${ }^{37}$. The pacifism of these Latin American feminist organizations was framed within a clearly PanAmericanist vision, since its members considered that they should form bonds with American women with whom they "had much in common".

Another of the magazines that appeared in South America at that time was "Mujeres de América", a magazine that reached 17 issues published between 1933 and 1935 and was directed by the journalist, writer and feminist Chilean resident in Buenos Aires, Nelly Merino Carvalho. The latter also maintained a friendship and close ties with both Delia Ducoing de Arrate and Rosa Borja de Icaza, and was also part of the International League of Iberian and Hispanic Women, of which she published many news articles.

The content of the magazine published bi-monthly did not differ at all from "Nuevos Horizontes" and "Nosotras". Many articles were devoted to feminism and the international feminist panorama, as well as to the struggle of women to maintain peace in the continent. The biographies of prominent feminist leaders on the continent were published in each issue. This is how one could read sketches about the Chilean Amanda Labarca, Delia Ducoing de Arrate, or the Bolivian Maria Luisa Sánchez Bustamante, founder of the main suffrage group in Bolivia, the Women's Athenaeum ("Ateneo Femenino"). The magazine and its director were in direct contact with Argentinian women's organizations as well as those of the continent.

Nelly Merino Carvalho also maintained particularly close ties with Bolivian writers, feminists and intellectuals in general. Apparently, these ties were created during the period of time that Nelly lived in Bolivia, before settling in Buenos Aires. Two issues of the magazine are dedicated to this country: one concerning Bolivian literature ${ }^{38}$ and the other concerning the Chaco $\mathrm{War}^{39}$. The greatest Bolivian writers and intellectuals of the time, as well as the most prominent feminists of that country collaborated in the magazine. This is the case of Franz Tamayo, María Frontaura Argandoña, Ana Rosa Tornero, María Luisa Sánchez Bustamante, Gloria Serrano, Etelvina Villanueva, etc. Etelvina Villanueva was one of the main collaborators in La Paz of the magazine, at the same time that she directed in those years next to Zoila Viganó Castañón the Committee of Feminist Action ("Comité de Acción Feminista") group that carried out an intense campaign for the feminine suffrage in Bolivia during the Chaco War. Etelvina Villanueva, who also maintained close ties with Rosa Borja de Icaza, would be the founder and president in 1935 of the Women's Legion of Popular Education in Bolivia, while Zoila Viganó would found and direct the Union of American Women of that country in the same year. As such, the magazines "Nosotras" and "Nuevos Horizontes", were exchanged with numerous other magazines of the continent.

The Chaco War was an omnipresent theme in the magazine: a whole issue was also devoted to articles on the role of Bolivian women in the war, and particularly of the feminist Ana Rosa Tornero, director of the Women's Union of Educationists of La Paz, who was at the head of the war to provide food and moral support to the soldiers with other women.

\footnotetext{
${ }^{37}$ Nuevos Horizontes, Year 2, July-August 1934, No9, Municipal Library of Guayaquil, Guayaquil, Ecuador.

${ }^{38}$ Mujeres de América, July-August 1933, №4, National Library of the Argentine Republic, Buenos Aires, Argentina.

${ }^{39}$ Mujeres de América, November-December 1934, Nº12, National Library of the Argentine Republic, Buenos Aires, Argentina.
} 
Along with other leaders of women's groups in Argentina, Nelly Merino Carvalho, sent a letter to the Minister of Foreign Affairs of that country, Carlos Saavedra Lamas, asking that Argentina continue its mediations for the cessation of hostilities in the Chaco. The letter was signed by: Nelly Merino Carvalho, as director of Women of America; Adelia di Carlo, President of the "Clorinda Matto de Turner" Association; Natalia Salles de Cogorno, President of the "Pro Mujer Peace Alliance"; Carmela Horne de Burmeister, President of the "Argentine Women's Suffrage Association"; Benjamina Quintana de Orzábal, President of the "Cordovan Ladies"; Dora Miranda, President of the "Women's Athenaeum" of Buenos Aires; María Zoraida Villarroel, President of the "Círculo Argentino Pro Paz"; Victoria Gucovsky, President of the "National Women's Association", and María C. de Spada, President of the "Children's Library and Recreation Association" 40 . Like Rosa Borja de Icaza, Nelly Merino Carvalho had the project to hold a Pan-American Congress that would basically deal with the rights of women in the continent and the maintenance of peace.

To all these feminist leaders of South America was also linked the commissioner for Mexico in the IACW, Margarita Robles de Mendoza through the organization that she founded in New York in 1934: The Union of American Women (UMA) that was already mentioned. From the beginning of the 1930s Margarita communicated to Doris Stevens her dream to create a continental feminist organization that would have branches in each of the countries of the Pan-American Union. This desire finally came to fruition once Margarita was in better economic conditions and after several years of struggle in an intensive campaign for women's suffrage in Mexico. This is how the UMA was born following the model of operation of the IACW. The organization had an International Council composed of one representative from each country of the continent whose headquarters were located in New York and in turn each country had a National Council that benefited from autonomy from the International Council as long as its objectives did not oppose the ideals of the UMA: the strengthening of ties between the women of the continent and the struggle for civil and political rights. The UMA had National Councils in Mexico, Bolivia, Cuba, Peru and Puerto Rico, and Ecuador as well as various affiliated associations such as the Women's Legions of Chile, the Uruguayan League Against the White Women Slavery, the Independent Feminist Democratic Party of Uruguay, the Uruguayan Women's League, the Civil Society of Mexican Women, the National Women's League of Mexico, the Women's Orienting League in Mexico, the Feminist Action of Bolivia, the Women's Suffrage League of Cuba, the National Feminist Alliance of Cuba, the Sunshine Club of Cuba, the Feminine Union of Sciences, Arts and Letters of Peru, the Women's Legion of Ecuador, and the Puerto Rican Legions of the $\mathrm{UMA}^{41}$.

Among the projects of Margarita was also the publication of a continental magazine that would be called "Mujeres" and that would count on the collaboration of the feminists of the continent as well as of the whole world. The magazine would be in circulation in 20 countries in the Americas and would be published in Spanish and English with the following

\footnotetext{
${ }^{40}$ Mujeres de América, Buenos Aires, May-June 1933, №3. National Library of the Argentine Republic, Buenos Aires, Argentina.

${ }^{41}$ Letter from Margarita Robles de Mendoza to Doris Stevens, February 28 ${ }^{\text {th }} 1935$, "Unión de Mujeres Americanas”, Boxes 92.1-92.2, Series V. Inter-American Commission of Women, Doris Stevens' Collection. The Arthur and Elizabeth Schlesinger Library on the History of Women in America.
} 
aim: “...to develop a better understanding among the women of the Spanish and English speaking countries and specially of the women of North and South America"42.

Apparently, this magazine never came into existence and despite the importance of the UMA, its traces left for posterity are almost non-existent. The main source of information about this organization are the personal archives of Doris Stevens and the feminist journals of the continent that published various news about the group.

The UMA had pacifist objectives like the other organizations of the continent. Like Rosa Borja de Icaza and Nelly Merino Carvalho, the women of the UMA planned the organization of an International Women's Congress that would take place in Lima in 1938 a few months before the Pan-American Conference took place in the same city where the IACW would play an important role. The objective was to coordinate efforts with the IACW to form a united front of women in that conference.

All these organizations maintained close ties with each other but also with all the feminist organizations in the continent with whom they exchanged magazines and with those who projected the organization of Pan-American women's congresses. The ties with the IACW, as we have already seen, were equally important. Just as they fought for the attainment of civil and political rights, these feminist organizations used their networks to fight for the maintenance of peace in the continent, a subject to which they dedicated many articles from their magazines but also intercontinental campaigns.

The logic by which we must understand the strategic reasoning of the feminists of the 1930s is this: if they were not considered legitimate interlocutors to discuss politics within their own countries, what they had to achieve was to obtain this legitimacy in a "transnational public sphere". In other words, if the "international public opinion" considered them legitimate interlocutors, consequently the public opinion of their countries would also do so and thus they could obtain political efficacy, that is to say, that their States granted them the rights they demanded. In that sense, they acted on two levels: the transnational and the national. These two levels allowed them to obtain the two conditioning elements of political efficacy according to Nancy Fraser ${ }^{43}$ : translation and capacity. Their demands were "translated" at an international level: their claims were made to international organizations that had the capacity to produce norms that could be potentially coercive (international treaties, recommendations, declarations, etc.). In that way, the international organizations were the ones that dealt with the translation of their demands "into binding laws". At a second level, these norms were to be established by sovereign States that had the administrative capacity to manage and make effective what the public opinion considered of common interest. Therefore, the feminists of the 1930s expected their States to sign international treaties that granted them their rights. This procedure could be achieved on the condition that they were considered legitimate interlocutors and that their demands were also considered legitimate. Internationally, peace was an issue that could naturally be considered legitimate to be legislated at the international level, but that was not the case for women's rights. Feminists therefore had to fight for their rights to be considered a legitimate issue to be legislated at the international level. This legitimacy was partly achieved with the creation of

\footnotetext{
42 Letter from Margarita Robles de Mendoza to Doris Stevens, 17 de enero de 1932, "Unión de Mujeres Americanas", Boxes 92.1-92.2, Series V. Inter-American Commission of Women, Doris Stevens' Collection. The Arthur and Elizabeth Schlesinger Library on the History of Women in America.

${ }^{43}$ Nancy Fraser, "Transnationalizing the Public Sphere. On the Legitimacy and Efficacy of Public Opinion in a Post-Westphalian World", in Transnationalizing the Public Sphere, ed. by Kate Nash (Polity Press, Cambridge, 2014).
} 
the IACW and with the circulation of feminist journals throughout the continent that aimed at raising awareness and influencing public opinion in favor of women's rights.

Despite knowing a moment of great activity in the 1930s, these feminist organizations had an ephemeral life and disappeared mostly at the end of the decade. In 1939 Doris Stevens was dismissed from her duties as president of the CIM and this organization lost much of its character and its feminist objectives, becoming a much less ambitious organization in terms of obtaining equality between men and women. Another era for the transnational feminist movement had started.

\section{Conclusions}

Through the meeting of the first professional women of the American continent in scientific congresses at the beginning of the century, the networks of solidarity, friendship, and communion of ideals and struggles of the American feminists of the first half of the $20^{\text {th }}$ century were woven. Being excluded from citizenship in their own countries, these women had to devise different strategies to obtain their rights. These women did not hesitate, therefore, to join at the international level in order to influence not only their countries but also at the transnational level through the search for political legitimacy and effectiveness. Through the networks that they wove, they were not only able to help themselves economically, but also to exchange information, tactics, and support of all kinds. The 1930s were a decade of apogee for these networks since most of the feminist organizations with an international vocation emerged at this time. The loss of autonomy of the IACW after the dismissal of Doris Stevens in 1939 as well as the disappearance of many of these organizations at the end of this decade allows us to consider that the following years constituted a different stage in the existence of these networks.

Therefore, analyzing the feminist movements of the American continent requires abandoning the national analytical frameworks that have been used up until now and adopting transnational perspectives that allow a better understanding of the way in which feminist organizations conceived their struggles and political strategies. Further research also needs to be done on the links of American feminists with international suffragist organizations from other continents. 


\section{Bibliography}

Primary sources

Archive of the Ministry of Cultures, Quito, Ecuador.

Municipal Library of Guayaquil, Guayaquil, Ecuador.

National Library of Chile, Santiago, Chile.

National Library of the Argentine Republic, Buenos Aires, Argentina.

The Arthur and Elizabeth Schlesinger Library on the History of Women in America, Radcliffe Institute for Advanced Studies, Harvard University, Boston, United States.

The New York Public Library, New York, United States.

The Library of Congress, Washington, United States.

\section{Secundary sources}

Alvarez, Sonia E. "Translating the global: effects of transnational organizing on local feminist discourses and practices in Latin America". Meridians: feminism, race, transnationalism 1, n. ${ }^{\circ} 1$ (2000): 29-67.

Auza Néstor Tomás. Periodismo y feminismo en la Argentina, 1830-1930. Buenos Aires, Argentina: Emecé Editores, 1988.

Ehrick, Christine. "Madrinas and Missionaries: Uruguay and the Pan-American Women's Movement". In Feminisms and Internationalism, Mrinalini Sinha, Donna Guy \& Angela Woollacott. Wiley, 1999.

Fraser, Nancy. "Transnationalizing the Public Sphere. On the Legitimacy and Efficacy of Public Opinion in a Post-Westphalian World". In Transnationalizing the Public Sphere, edited by Kate Nash. Polity Press, Cambridge, 2014.

Goetschel, Ana María. Orígenes del feminismo en el Ecuador: Antología. Quito: CONAMU, 2006.

Grewal, Inderpal. Transnational America. Feminisms, diasporas, neoliberalisms. Durham \& London: Duke University Press, 2005.

Hahner, June Edith. Emancipating the female sex: the struggle for women's rights in Brazil, 1850-1940. Durham: Duke University Press, 1990.

Lee, Muna. "The Inter-American Commission of Women. A New International Venture". In A Pan-American Life: Selected Poetry and Prose of Muna Lee. Univ. of Wisconsin Press, 2004. 
Lavrin, Asunción. Women, feminism, and social change in Argentina, Chile, and Uruguay, 1890-1940. Lincoln, Neb.: University of Nebraska Press, 1995.

. The ideology of feminism in the Southern Cone, 1900-1940. Washington, D.C. Smithsonian Institution Bldg., Washington 20560: Latin American Program, the Wilson Center, 1986.

Luna, Lola G. El sujeto sufragista, feminismo y feminidad en Colombia 1930-1957. Cali: La Manzana de la Discordia, 2004.

Macías, Anna. Against all odds: the feminist movement in Mexico to 1940. Westport, CT: Greenwood Press, 1982.

Marx Ferree, Myra and Aili Mari Tripp, ed. Global feminism. Transnational women's activism, organizing, and Human Rights. NYU Press, 2006.

Miller, Francesca. "The International Relations of Women of the Americas, 1890-1928". The Americas: A Quarterly Review of Inter-American Cultural History 43, n. ${ }^{\circ} 2$ (1986): 171-182.

Latin American women and the search for social justice. Hanover: University Press of New England, 1991.

. "Latin American Feminism and the Transnational Arena". In Women, Culture, and Politics in Latin America. Emilie Bergmann, Janet Greenberg, Gwen Kirkpatrick, Francine Masiello, Francesca Miller, Marta Morello-Frosch, Kathleen Newman and Mary Louise Pratt. University of California Press, 1992. doi10.1525/california/9780520065536.001.0001.

."Feminism and Foreign Policy in the Americas: Separate Conversations?". WAWH Conference XXVI, California, June 3, 1995.

Offen, Karen, ed. Globalizing Feminisms, 1789- 1945, 1 edition. London; New York, Routledge, 2009.

Olcott, Jocelyn. Revolutionary women in postrevolutionary Mexico. Durham: Duke University Press, 2005.

Prieto, Mercedes \& Ana María Goetschel. "E1 sufragio femenino en el Ecuador, 1884-1940”. In ¿Qué género tiene el derecho? Ciudadanía, historia y globalización, edited by Stefanie Kron \& Karoline Noack. Berlín: Edition Tranvía, Verlag Walter Frey, 2008.

Rupp, Leila J. Worlds of Women: The Making of an International Women's Movement. Princeton, N.J: Princeton University Press, 1997.

Sinha, Mrinalini, Donna Guy et Angela Woollacott. Feminisms and Internationalism. Wiley, 1999. 
Sosa Estela Mary. El papel de las mujeres paraguayas en la Guerra del Chaco (1932-1935): relaciones de género en contexto bélico. Posadas, Misiones, Argentina: Editorial Universitaria, Universidad Nacional de Misiones, 2010.

Soto Shirlene. Emergence of the Modern Mexican Woman: Her Participation in Revolution and Struggle for Equality, 1910-1940. Denver, CO: Arden Press Inc., 1990.

Stoner, K. Lynn. From the house to the streets: the Cuban woman's movement for legal reform, 1898-1940. Durham, Duke University Press, 1991.

Threlkeld, Megan. Pan-American Women: U.S. Internationalists and Revolutionary Mexico. University of Pennsylvania Press, 2014.

Tunón Julia. Voces a las mujeres: antología del pensamiento feminista mexicano 1873-1953. México, D.F.: Universidad Autónoma de la Ciudad de México (UACM), 2011. 